\title{
THEORETICAL AND METHODOLOGICAL PROBLEMS OF RESEARCH OF HISTORIOGRAPHY OF MUSEUM MOVEMENT ON PRIKARPATHIAN REGION IN SECOND HALF OF THE XIX CENTURY - 30S OF XX CENTURY
}

\section{ТЕОРЕТИКО-МЕТОДОЛОГІЧНІ ПРОБЛЕМИ ДОСЛІДЖЕННЯ ІСТОРІОГРАФІЇ МУЗЕЙНИЦТВА НА ПРИКАРПАТТІ ДРУГОЇ ПОЛОВИНИ ХІХ - 30-Х РР. ХХ СТОЛІТТЯ}

\section{Olena Dutchak ${ }^{1}$}

DOI: https://doi.org/10.30525/978-9934-588-38-9-48

Abstract. On pages of tht article theoretical and methodological problems of the historiography of museums in the Precarpathian region of the second half of the 19th -30 s of the 20th century are researched. All terminological problems is identified. The meaning of the terms «museum work», «museum studies», «museuming» is outlined. The chronological boundaries of the study were determined. They have two levels. The first level is the territory of the Precarpathian region, which for today, almost completely coincides with the administrative borders of the Ivano-Frankivsk region. The second level has a global scale - scientific works of scientists all over the world.

In the scientific and historical researches of the development of museums in the Precarpathian region of the second half of the XIX - 1930's XX century the following historiographical periods can be distinguished: historiography of the second half of the XIX - the beginning of the XX century, scientific studies of the 20-30's of the XX century, Soviet (post-war) historiography, and contemporary Ukrainian historiography. In each of the above periods, there were excellent methodological approaches, ideological attitudes and epistemological capabilities.

The main blocks of the source base of the historiography of museuming in the Precarpathian region of the second half of the XIX - 30's of the $\mathrm{XX}$ century are outlined. It is a wide range of historiographical sources:

${ }^{1}$ Candidate of Historical Sciences, Associate Professor,

Vasyl Stefanyk Precarpathian National University, Ukraine 
scientific and educational literature, conference materials, reference books, memoirs, archival sources.

The historiography of museums in the Precarpathian region of the second half of the nineteenth - 1930's. consists of a number of problems: the activities of prominent personalities, private collections, museums of cultural and educational societies, local lore and ethnographic activity.

The methodological basis of the study is a set of general scientific and special methods of scientific knowledge that are traditionally used in historiographic studies: logical, comparative, retrospective, methods of classification, periodization, scientometry, historical analysis, synthesis, system-structural and problematic approach, historical-chronological situation, etc. It is important to involve the methodological achievements of world historical science.

The methodological toolkit of modern Ukrainian science makes it possible to carry out a comprehensive historiographical study of museuming in the Precarpathian region of the second half of the XIX - 30's of the $\mathrm{XX}$ century. This was not a solved scientific problem at this time.

\section{1. Вступ}

Дослідження історіографії музейництва на Прикарпатті другої половини XIX - 30-х pp. XX ст. акумулює низку теоретико-методологічних проблем, які визначають сутність історіографічного дослідження музейництва Прикарпаття другої половини XIX - 30-х pp. $\mathrm{XX}$ століття, окреслюють рамки досліджуваного явища, дозволяють визначити його структурні компоненти. Метою дослідження виступає комплекс теоретико-методологічних проблем дослідження історіографії музейництва на Прикарпатті другої половини XIX - 30-х pp. $\mathrm{XX}$ ст., до яких можна віднести: термінологічні та джерелознавчі проблеми, хронологічні та територіальні рамки розвитку історіографічного процесу тощо. 3 огляду на це, завданнями дослідження виступає вирішення комплексу теоретико-методологічних проблем: вивчення дискусійних термінологічних проблем, обгрунтування територіальних рамок дослідження, визначення хронологічної детермінації музейництва на Прикарпатті другої половини XIX - 30-х pp. XX ст., окреслення джерельної бази історіографічного дослідження, окреслити внутрішні зв’язки та структурні компоненти музейництва на Прикарпатті. 
Методологічною основою дослідження виступає комплекс загальнонаукових та спеціальних методів наукового пізнання, що неодноразово апробовані та довели свою актуальність бути надалі застосованими у історіографічних дослідженнях: логічний, порівняльний, ретроспективний, методи класифікації, періодизації, наукометрії, історичного аналізу, синтезу, системно-структурного і проблемного підходу, історико-хронологічний, історико-ситуаційний тощо. Логіка процесу дослідження та, відповідно, викладу результатів обумовлена послідовністю, що полягає у окреслені зовнішніх, рубіжних проблем досліджуваного явища, а лише згодом - аналізу внутрішніх, структурних аспектів та взаємозв'язків.

Напрацьований українською історичною наукою методологічний інструментарій дає змогу здійснити комплексне історіографічне дослідження музейництва на Прикарпатті другої половини XIX 30-х pp. XX ст. НА сьогодні у сучасній історичній науці немає жодного узагальнюючого історіографічного дослідження проблем формування та розвитку музейництва на Прикарпатті.

\section{2. Термінологічні проблеми}

Використання терміну «музейна справа» в українській історичній науці безе початок ще з так званого «протомузейного» періоду, коли впродовж кількох століть проходив процес збору різноманітних колекцій, формування музейних установ та зародження основних напрямків музейної роботи. Термін «музейна справа» $є$ традиційним в українській історичній науці та позначає спеціальну галузь культурно-освітньої та наукової діяльності, яка здійснюється музеями з метою комплектування, збереження, вивчення й використання пам'яток природи, матеріальної та духовної культури [8, с. 11].

Відповідно до Закону України «Про музеї та музейну справу» від 29 червня 1995 року № 249/ 95-ВР термін «музейна справа» позначає такі напрямки діяльності, як культурно-освітня, експозиційна, фондова, видавнича, реставраційна, пам'яткоохоронна та науково-дослідна діяльність [2].

Поряд 3 ним вживається термін «музеєзнавство», який використовується для позначення наукового напрямку, навчальної дисципліни та 
методик побудови музейних експозицій, виставок, різних видів і форм науково-освітньої діяльності музеїв [8, с. 13-15].

Гносеологічний зміст терміну «музеєзнавство» передбачає його трактування як існуючі знання та засади отримання нових знань про основні аспекти музейної справи. Цей термін не позначає всієї сукупності науково-дослідних, аксіологічних, функціонально-праксеологічних проблем, що стосуються музеїв та музейної справи.

Уніфікованим та загальновживаним у міжнародній практиці терміном, що $€$ виявом нової постіндустріальної музеологічної парадигми, $€$ музеологія [1;8]. Вона структурно поділяється на окремі наукові напрямки: метамузеологія (науково-теоретичне підгрунтя музеології), історична музеологія (вивчає час, місце та умови виникнення музеального феномену), теоретична музеологія (систематизація досягнень теоретичного мислення та результатів, що виникли під час збирання, опису та впорядкування фактів [1, с. 37-38].

Стосовно терміну «музеологія» українські науковці М.Й. Рутинський, О.В. Стецюк роблять певні застереження щодо можливості його застосування в реаліях української історичної науки. Обгрунтовуючи це тим, що досвід здійснення наукових досліджень української історичної науки сягає лише півтори сотні років [8, с. 14].

Когортою українських науковців - представників різних наукових напрямків (істориків, культурологів, мовознавців) здійснено ряд цікавих досліджень, присвячених проблемам термінології музейної справи України. Серед досліджуваних ними проблем, вагоме місце займає питання визначення та конкретизація дефініції, що окреслює власне наукові дослідження практичних та теоретичних аспектів розвитку музейної справи з урахуванням українських наукових реалій.

Важливість термінологічних проблем української музейної справи та музеєзнавства засвідчує той факт, що такі дослідження було здійснено при Інституті історії України НАН України [3].

Так, київська науковець і громадська діячка, старший науковий співробітник відділу історичної регоіналістики Інституту історії України НАН України Р. Маньковська на сторінках власних дослідження [6] пропонує використовувати термін «музейництво» як найбільш відповідний до реалій та методологічних напрацювань скачаної української історичної науки. 


\section{3. Хронологічні рамки}

Хронологічні рамки дослідження історіографії музейництва на Прикарпатті другої половини XIX - 30-х pp. XX ст. можна простежити у двох вимірах Перший рівень визначається хронологічними межами розвитку музейної справи на Прикарпатті.

Нижня хронологічна межа - середина XIX ст. - час, коли краєзнавчо-етнографічні мандрівки теренами Прикарпаття, колекціонування та музеєфікація різних артефактів набирає обертів. Створюються приватні колекції, засновуються окремі музейні збірки при громадських організаціях та різноманітних осередках культурного життя. Якщо протягом першої половини XIX ст. цей процес тільки починає зароджуватися, то з середини XIX ст. стає більш інтенсивним та, відповідно, більш висвітленим на сторінках наукових праць.

Верхня межа досліджуваного історичного явища є дуже чіткою кінець 30-х рp. XX ст., а саме вересень1939 року - початок радянської окупації Західної України. Із зміною державно-політичної системи та встановленням тоталітарного режиму, відбулися кардинальні зміни у культурному житті. Переведено суспільні інституцій на чітко регламентовані ідеологічні засади функціонування. Регламентованість, чітка плановість діяльності, жорсткі ідеологічні рамки докорінно змінюють функції таких культурно-освітніх інституцій, як музеї. Можна чітко простежити цілий ряд змін, що визначили так званий «вододіл» у періодизації музейництва на Прикарпатті, що окреслює певну завершеність попереднього періоду i, за наявними якісними ознаками, окреслює початок наступного.

3 другої половини XIX i до 30-х pp. XX ст. музейна справа базувалася на патріотизмі, особистій чи інституційній ініціативі та була наслідком історико-краєзнавчого, фольклорно-етнографічного вивчення території Прикарпаття дослідниками різної національної приналежності. Це були, як правило, відомі громадські діячі того часу. Така робота здійснювалась ними на основі власної ініціативи, наукових інтересів. Музейництво того часу мало дещо спорадичний характер, що притаманне періоду становлення та накопичення музейних пам'яток. Такими музеаліями ставали в основному артефакти, як етнографічно-ужиткового, так і мистецького характеру, а також різноманітні предмети старовини, в тому числі книги, стародруки. Формування 
бібліотечних зібрань проходило паралельним процесом до формування музейних зібрань. Це пояснюється тим, що часто збором артефактів, що згодом ставали музейними пам'ятками, та книг займалися одні і ті ж особистості. У радянський період індивідуально-ініціативна діяльність краєзнавців, музейних працівників має виражений інституційний характер, визначені рамки діяльності. Краєзнавчі дослідження стають більш орієнтованими на природничо-географічний напрямок.

У період другої половини XIX - 30-х рp. XX ст. музеї на території Прикарпаття мали переважно вигляд приватних зібрань, музеїв культурно-освітніх товариств, еклектичних колекцій книг, стародруків, предметів старовини та художніх творів. Було засновано музеї, що у наш час містять музейні колекції національного значення та на увесь світ репрезентують автентичну культуру етнографічних груп Прикарпаття (для прикладу - Національний музей народного мистецтва Гуцульщини та Покуття імені Йосафата Кобринського).

Музейні зібрання досліджуваного періоду виконують функції збереження, примноження та трансляції культурних цінностей відповідно до запитів суспільства того часу. Напевне, головним здобутком музейних колекцій другої половини XIX ст. є збереження унікальних предметів старовини етнографічного, мистецького характеру та предметів побуту відомих діячів. Ці артефакти пізніше стали не лише надбання культурної спадщини, а основою існуючих сьогодні музейних установ.

3 початком 40-х років музеї стають державними установами та виконують покладені на них функції. Крім ідеологічно-виховних, музеї виконують вкрай важливу для радянської тоталітарної системи функцію так званого «контрольованого дозвілля» - заняття всього вільного часу радянського громадянина окремими видами діяльності для тотального контролю та посилення ідеологічного впливу.

Основними відвідувачами музейних зібрань до початку 1940-х рр. були елітарні групи тодішнього суспільства, інтелігенція, науковці, члени молодіжних та просвітницьких товариств. У радянський період основними відвідувачами музеїв є організовані групи, що формуються з робітників підприємства, школярів, студентської молоді. Музеї стають орієнтованими на задоволення культурних потреб масового відвідувача.

Музейна справа у радянський період, як і вся соціогуманітарна сфера, розвивається у рамках жорсткої цензури. Знищуються, без- 
слідно зникають безцінні речі сакрального характеру, відповідно закриваються і знищуються цілі музейні зібрання, присвячені українським визвольним змаганням, державному будівництву, видатним українським діячам. Практично аналогічною доля колекцій польських, німецьких діячів. Натомість засновуються музеї присвячені партійцям, керівникам радянського державного апарату.

Другий рівень - хронологічні межі розвитку власне історіографічного процесу. Він розпочався практично одночасно з процесом формування музейництва на Прикарпатті другої половини XIX - 30-х pp. XX ст. Вже тоді було здійснено спроби опису, систематизації та наукового аналізу наявних колекцій. 3'являються праці історико-краєзнавчого та народознавчого характеру, присвячені також музейній проблематиці.

У науково-історичному процесі процес музейництва Прикарпаття другої половини XIX - 30-х pp. XX ст. можна виокремити такі періоди: історіографія другої половини XIX - початку XX ст., дослідження 20-30-х pp. XX ст., радянська (післявоєнна) історіографія, сучасна українська історіографія. Прикметно, що перші два періоди представлені суб'єктами історичного пізнання різної етнічної приналежності.

Окремим блоком можна виділити діаспорну історіографію, хронологічні рамки якої повністю співпадають 3 Новітньою епохою. Це хронологічний відрізок впродовж всього ХХ століття - від Першої світової війни і до сьогодні. Цей відносно малочисельний комплекс історіографічних джерел, присвячений розвитку музейництва на Прикарпатті, також можна співвіднести з певними хронологічними періодами та виокремити декілька етапів: міжвоєнна історіографія, історіографія другої половини XX ст. (післявоєнна) та сучасна (кінець XX - початок XXI ст.).

Розвиток історіографічного процесу на кожному з історіографічних етапів зазнавав значних методологічних, гносеологічних, світоглядних, ідеологічних та інших трансформацій. Процес розвитку історіографічного процесу триває і сьогодні, акумулюючи сучасні методологічні напрацювання української та світової історичної науки. Історіографічний процес завжди спрямований у майбутнє, оскільки проблематика будь-якого історичного періоду знаходить і знаходитиме своє наукове відображення на сторінках новітніх наукових праць, щоразу актуалізуючись у новому контексті. 


\section{4. Територіальні межі}

3 огляду на специфіку історіографічного дослідження, територіальні рамки дослідження історіографії музейництва на Прикарпатті другої половини XIX - 30-х pp. XX ст. мають двохрівневий характер. Перший рівень територіальних меж досліджуваного явища окреслений комплексом історичних, географічних, економічних, етнічних,соціокультурних чинників, що визначають межі регіону Прикарпаття, його цілісність та внутрішньо регіональні взаємозв'язки, який на сьогодні практично повністю співпадає з адміністративними межами Івано-Франківської області.

Другий рівень характеризується загальнопланетарним масштабом. Він представлений історіографічними джерелами досліджуваної проблеми - науковими працями, що вийшли з під пера науковців будь-якої національної чи територіальної приналежності у часовому проміжку від середини XIX ст. до кінця 30-х рр. XX ст. Це, здебільшого, праці українських, польських, німецьких, єврейських та інших вчених, написані у різні часові періоди, що більшою чи меншою мірою присвячені розгляду музейництва на Прикарпатті другої половини XIX - 30-х рр. XX ст. Виділення за територіальним принципом діаспорної історіографії як окремої когорти науковців $є$ дещо умовним. Під діаспорною історіографією розуміємо українських вчених, що написали свої праці, присвячені музейництву на Прикарпатті другої половини XIX - 30-х pp. XX ст., проживаючи за межами України. Варто брати до уваги також наукові напрацювання науковців різних національностей, що підготували наукові доробки, перебуваючи за межами українських земель.

\section{5. Джерельна база}

Дослідження історіографії музейництва на Прикарпатті другої половини XIX - 30-х рр. XX ст. базується на значному за обсягом корпусі історіографічних джерел. Мультиаспектність досліджуваного явища та його суспільна значущість є однією з причин наявності великої кількості досліджень, підготовлених у різні хронологічні періоди.

Вся сукупність наукових праць, що хоча б якоюсь мірою відображають розвиток музейної справи на Прикарпатті другої половини XIX 30-х pp. XX ст. формують джерельну базу історіографії музейництва на Прикарпатті другої половини XIX - 30-х pp. XX ст. Саме вся без винятку 
сукупність історіографічних джерел дозволяє максимально об'єктивно дослідити історико-науковий процес у всій його повноті, виявити провідні тенденції, визначити певні закономірності розвитку історичної думки, 3'ясувати найхарактерніші досягнення, труднощі, недоліки [4, с. 19].

Джерельна база історіографії музейництва на Прикарпатті другої половини XIX - 30-х pp. XX ст. сформована різновидами джерел, характерними для всіх періодів розвитку науково-історичного процесу. Основну групу історіографічних джерел становлять наукові дослідження (опубліковані та незначна кількість рукописних), підготовлених у часовому проміжку середини XIX - початку XXI ст., а саме монографії, наукові статті, навчально-методичні видання, тези, брошури, розділи різнотематичних збірників, матеріали зібрань наукових товариств та наукових конференцій, наукові записки, література мемуарного характеру та окремі збірки архівних документів, що містять описи колекцій, записи тих,хто займався збиранням артефактів, тощо.

Важливим $є$ значення навчально-методичні видання (підручники, навчальні посібники), довідкові та науково-популярні видання, які відображають досягнення науки у час їх створення. Значно меншою науковою вартістю характеризуються публіцистичні твори, що ілюструють інтелектуальне та ментальне тло суспільства у певний період часу.

Інформативною є така група історіографічних джерел, як бібліографічні та біобібліографічні довідники, огляди, відгуки та рецензії. Вони одночасно виступають історіографічними джерелами та власне самостійними історіографічними працями. Провідні інституції у галузі бібліографознавства, бібліології , такі як Книжкова палата України, Національна бібліотека імені В.І. Вернадського, Історична та інші бібліотеки регулярно видають бібліографічні покажчики, в т.ч. історико-тематичні, що дають уявлення про кількісні параметри праць, так і про їхню тематичну спрямованість. Такі огляди наукових праць $\mathrm{i}$ рецензій містять оцінку фахівців тих чи інших праць, часто історіографічну [4, с. 20-21]. Наявність таких видань певною мірою полегшує пошукову діяльність суб'єкта історіографічного дослідження, дозволяє оптимізувати евристичну діяльність науковця.

Потрібними для об'єктивного висвітлення досліджуваного явища $є$ історіографічні пам'ятки - джерела особового походження. Це записи, рукописи праць, автобіографії, щоденники, листи, мемуари, особисті 
архівні збірки осіб, що мали безпосереднє відношення до музейної справи на Прикарпатті середини XIX - початку XXI ст. Так, важливими є джерела особового походження Й. Кобринського, І. Франка та його сподвижників, польських мандрівників, краєзнавців.

Конкретизація фактографічного матеріалу, зокрема організаційних аспектів розвитку досліджуваних процесів (засад функціонування музейних інституцій, громадських організацій культурно-просвітницького характеру, фактів з життя і діяльності видатних громадських діячів Прикарпаття, що мали вплив на розвиток музейної справи, умов діяльності науковців різних історіографічних періодів, тощо) неможлива без використання джерел документального характеру. Хоча загальновизнаним фактом в українській історичній науці $є$ те, що в історіографічних дослідженнях така група джерел має не те тільки не основне, а загалом додаткове, конкретизуюче, допоміжне значення.

Історіографічне дослідження полягає у вивченні генези історичних знань, розвитку науково-історичного процесу, дослідженні стану історичної науки у той чи інший період часу [4, с. 22]. Тенденції розвитку історичної науки, нові концепції та знання мають також вплив на суспільство та значною мірою обумовлюють тенденції розвитку науки наступних історіографічних періодів. Саме тому історіографічний аналіз джерельної бази необхідно здійснювати у нерозривному зв'язку iз загальнокультурним контекстом того історіографічного періоду, у часовому проміжку якого виникло дане історіографічне джерело.

Проблематика музейництва Прикарпаття другої половини XIX 30-х рр. ХХ ст. (видатні особистості музейної справи, музеї громадських організацій і товариств, краєзнавча діяльність та формування окремих музейних зібрань) обумовила багаточисельність, неоднорідність та різножанровість джерельної бази.

Характерною особливістю джерельної бази історіографії музейництва Прикарпаття другої половини XIX - 30-х pp. XX ст. виступає різна етнічна приналежність авторів наукових праць. Це, в основному, стосується доробків, що були підготовлені з другої половини XIX і до кінця 30-х pр. XX ст. Їхніми авторами були українці, поляки, німці, євреї та представники інших національностей, що проживали на території Прикарпаття, яке входило до складу різних держав. У досліджуваний період цей регіон перебував у складі Австро-Угорщини, ЗУНР та Польщі. 


\section{6. Структурні компоненти наукової проблеми}

Структурно історіографічний процес музейництва Прикарпаття другої половини XIX - 30-х pp. XX ст. можна поділити на декілька етапів, що характеризується внутрішньою єдністю та чітко вираженою специфікою методології проведення досліджень, тематикою, тощо.

У науково-історичному дослідженні розвитку музейництва Прикарпаття другої половини XIX - 30-х pp. XX ст. можна виокремити такі історіографічні періоди: історіографія другої половини XIX - початку XX ст., наукові дослідження 20-30-х рр. XX ст., радянська (післявоєнна) історіографія та сучасна українська історіографія. У кожному 3 вище названих періодів спостерігалися відмінні методологічні підходи, світоглядні установки та гносеологічні можливості. Впродовж кожного з історіографічних періодів існували так звані «наукові традиції», пов'язані з наслідуванням діяльності визначних науковців, та суттєві гносеологічні обмеження, як, наприклад, у радянський період.

Цікавою, але зрозумілою, є особливість конкретизації предметного поля у дослідженнях вчених другої половини XIX - 30-х років XX ст. Вчені, поляки за етнічним походженням, зосереджували свою увагу на внеску у культуру, науку, мистецтво та інші сфери життя поляки, як і представники інших національностей - на власних здобутках. Це стало однією з причин відсутності комплексних узагальнюючих досліджень музейництва Прикарпаття другої половини XIX - 30-х років XX ст. Проблема відсутності комплексних наукових досліджень, як фактографічного, так і історіографічного характеру, здійснених на високому академічному рівні.

Важливою науковою проблемою, характерною для всіх періодів української історіографії, що досі існує в українському науковому просторі, виступає україноцентризм. Україноцентризм традиційно виступає світоглядною позицією українських науковців. Такий підхід настільки вкорінився у практику наукових досліджень, що на сьогодні практично втратив всі ознаки суб'єктивізму та виступає базовою методологічною основою вивчення будь-яких наукових проблем, які мають територіальний чи змістовний стосунок о території України, української нації та проводяться українськими вченими.

Така позиція могла бути виправданою на невеликому часовому проміжку після відновлення державної незалежності України, коли укра- 
їнська історична наука характеризувалась наявністю так званих «білих плям» окремих проблем української історії, відсутністю провідних світових дослідницьких методик та методологічних напрацювань, відсутністю досвіду проведення узагальнюючих наукових досліджень на основі наукового космополітизму, об’єктивності, неупередженості та високопрофесійної наукової компетенції.

На сьогодні абсолютизація україноцентризму в історичних дослідженнях, вивчення будь-яких фактів чи процесів виключно 3 позицій титульної нації виступає не таким вже й продуктивним. Більше того, виключний україноцентризм виступає гальмом наукового поступу та бар'єром включення до наукового обігу української історичної науки, як нових фактів, так новітніх методологічних напрацювань. Факторами, що підсилюють проблеми залучення нових науково верифікованих відомостей до наукового обігу української історичної науки та застосування нової дослідницької методології є знання іноземних мов сучасними українськими науковцями та певною мірою недостатня комунікація між вченими різних країн світу.

Специфікою праць наукового та публіцистичного характеру, що вийшли у світ у часовому проміжку другої половини XIX - 30-х років $\mathrm{XX}$ ст. виступає синкретизм, коли на сторінках однією праці розкрито проблематику, що належить до історії, краєзнавства, музеєзнавства,соціології, мистецтва, національно-культурного життя тощо. Характерною $є$ така особливість для праць авторів будь-якої етнічної приналежності. Це особливість, що ілюструє розвиток науки того часу загалом, коли кристалізація наук ішла шляхом відокремлення вузьких наукових напрямків від більш загальних та нерозчленованих у науковому плані досліджень.

Структурно у самій проблематиці музейництва Прикарпаття другої половини XIX - 30-х років XX ст. можна виділити кілька тематичних блоків, які слід піддати історіографічному аналізу: краєзнавчо-етнографічні дослідження та походи, що привели до накопичення музейних пам'яток; формування приватних колекцій та заснування музеїв; діяльність музеїв «Просвіти», інших громадських організацій; видатні громадські діячі та науковці, що здійснили вплив на формування музейництва на Прикарпатті тощо. 


\section{7. Методологічні засади дослідження}

Тривалий період сучасної української історіографії верифікація методологічних основ і постановка категорії історизму була пов'язана з подоланням та відкиданням марксистських ідеологічних засад. Вчені, що займалися вивченням проблематики української історіографії, займалися переважно пошуками різнопланових концепцій та структуруванням історичної думки, що має пояснити зміну наукових парадигм [5]. Цей період тривав від часу відновлення української незалежності до початку XXI ст. Впродовж останнього десятиліття триває процес не тільки часткової інтеграції новітніх світових напрацювань до практики наукових досліджень українських вчених, а й розвиток власних напрацювань, що формувалися українській історичній науці у попередні періоди.

На думку видатного київського вченого, у цьому контексті важливим завданням є розв'язання проблеми, чому концептуальні засади й науково-теоретичні принципи, розроблені в національній історіографії наприкінці XIX - поч. XX ст., залишаються актуальними і в сучасній українській історіографії, яка певною мірою досі функціонує у межах пізнавального простору й наукових парадигмах цієї методологічної епохи [7, с. 3-22].

Можна стверджувати, що на сьогодні, українська історіографічна науко послуговується методологічною основою, що є комбінацією наукових парадигм кінця XIX - початку XX ст., «новими віяннями» кінця XX - початку XIX ст.

Головним методологічним орієнтиром історіографічного дослідження музейництва Прикарпаття другої половини XIX - 30-х років $\mathrm{XX}$ ст. є чітке дотримання принципів історизму, об'єктивності. Об'єктивне історіографічне дослідження передбачає врахування контекстів тих історико-культурних та історіографічних реалій, які стали предметом вивчення.

Одним з найістотніших критеріїв історіографічного дослідження $є$ характеристика принципів та методів дослідження, які реалізуються через систему історичного мислення. На думку більшості науковців-теоретиків історії історичної науки, саме зміна історичного мислення є домінантною рушійною силою процесу історичного пізнання взагалі [5]. Саме така зміна у науковому мисленні, сприйнятті, гносео- 
логічних можливостях уможливлює виокремити ті концептуальні зрушення у вивченні фактів минулої дійсності, що дають змогу визначити межу між окремими історіографічними періодами.

Сучасна історична наука грунтується на багатьох формоутворюючих принципах: історизму, об'єктивності, логіки тощо. Як вважає відомий науковець О. Кіян, з позицій внутрішньої логіки історіографії, найбільш доцільним підходом для синтезу видається сцієнтистський (науковий) принцип вивчення минулого історичної епохи, спрямований на з'ясування механізмів виникнення й зміни історичних ідей та концепцій [5].

Відповідно до сцієнтизму,усі види історіографічних досліджень досконалі лише тією мірою, якою вони наслідують існуючі наукові парадигми та перебувають у прямій залежності від рівня розвитку історичної науки загалом, від історичних знань, методології дослідження, історичної теорії.

Окрім того, історіографічний сцієнтизм має перебувати у безпосередньому зв'язку із загальними проблемами історичної науки, ії нових надбань. Простежуючи шляхи розвитку історичного пізнання, сцієнтизм як базова засада розвитку історичної науки, уможливлює з'ясувати рушійні сили прогресу історичної думки, закономірності появи й зміни різних напрямів, шкіл,творчості осібних учених, генераторів ідей, міру достовірності створених ними концепцій, значення останніх для суспільного процесу певного часу [5].

Основною вимогою історіографічного сцієнтизму виступає критична перевірка раніше використаних засобів і методів інтерпретації історичного знання, зроблених висновків та теоретичних узагальнень. Це стає вкрай необхідним та обов'язковим у результаті появи у процесі розвитку історичної науки нових знань і змістових методологічних новацій в інтерпретації раніше відомих фактів, нових методологічних зрушень, а також виступає важливим компонентом взаємозв'язку, тяглості історіографічного дослідницького процесу.

Підгрунтям історіографічного дослідження музейництва Прикарпаття другої половини XIX - 30-х pp. XX ст. є певною мірою традиційний комплекс загальнонаукових та спеціальних методів наукового дослідження. Це не просто сукупність випрацюваних та адаптованих історичною наукою методів, а їх специфічне поєднання, обумовлене 
логікою процесу наукового дослідження, завданнями, специфікою досліджуваного предмета та джерельної бази, іншими аспектами. Доречними при здійсненні історіографічного дослідження $є$ використання таких методів, як логічний, порівняльний, ретроспективний, методи класифікації, періодизації, наукометрії, історичного аналізу, синтезу, історико-хронологічний, історико-ситуацйний, системно-структурного і проблемного підходу тощо.

Цікавим та продуктивним для історіографічних досліджень методом наукового пізнання є аналогія, за іiі допомогою можна отримати нові знання про об' єкти чи явища на основі того, що вони є подібні до інших. Метод дозволяє групувати історіографічні факти, виявляти аналогічні наукові праці в межах одного чи кількох історіографічних періодів.

Важливим при розгортанні історіографічних досліджень є гіпотетичний метод пізнання. Цей метод передбачає формування наукового передбачення, яке формулюється на основі багатьох інших методів наукового досліджену: аналітико-синтетичної діяльності, порівняння та інших. В історіографічних дослідженнях гіпотетичний метод пізнання дозволяє визначити рамки здійснення дослідження, здійснити орієнтовний розподіл історіографічного процесу на окремі періоди.

Абсолютно придатним для історіографічного дослідження музейництва Прикарпаття другої половини XIX - 30-х pp. XX ст. виступає метод абстрагування, яке дозволяє замінити в свідомості науковця складний процес (досліджуване явище) більш простим для сприйняття, виділити найсуттєвіші його ознаки.

Актуальним в українській та світовій історичній науці залишається системний підхід до вирішення дослідницьких проблем надзвичайно широкого спектру наукових досліджень. Системність в історіографічному дослідженні є основою вичерпного, а у наслідку, максимально об'єктивного аналізу історіографічних джерел кожного науково-історичного періоду. Вся сукупність історіографічних джерел розглядається як система, структурована певними закономірностями, внутрішніми взаємозв'язками. Аналіз саме взаємопов'язаної системи надасть змогу отримати системні висновки та наукові результати.

Успішне здійснення історіографічного, як і будь якого іншого історичного дослідження неможливе без аналітико-синтетичної діяльності науковця, що полягає у послідовному застосуванні методів аналізу 
та синтезу щодо окремих історіографічних джерел, відомостей, що містяться на сторінках наукових праць, так і наявної інформації щодо цілих історіографічних періодів.

Найбільш уживаним та, безсумнівно, актуальним науковим методом, що використовується практично всіма існуючими сьогодні науками та міждисциплінарними науковими напрямками, $є$ метод порівняння. Його застосування в історіографічних дослідженнях проявляється у встановленні подібності, цілковитої тотожності чи відмінності та їхнього ступеня вираженості між окремими науковими працями, науковими школами, напрямками, науково-історичними періодами.

Проблематика самого історіографічного дослідження музейництва Прикарпаття другої половини XIX - 30-х pp. XX ст.: збір та функціонування приватних колекцій, індивідуально-ініціативна діяльність аматорів музейної справи, формування музейних збірок при громадських організаціях та інші аспекти наближають історіографічне дослідження до теоретичних узагальнюючих досліджень соціоісторії, історії повсякденності, мікроісторії, нової культурної історії, локальної історії, яка насправді є дуже відмінною від краєзнавства, та інших, як сучасних, так традиційних для світової історичної науки наукових напрямків.

\section{8. Висновки}

У результаті вивчення та осмислення ключових проблем історіографічного дослідження музейництва Прикарпаття другої половини XIX - 30-х pp. XX ст. можна зробити низку наступних висновків:

По-перше, серед проблем історіографічного дослідження музейництва Прикарпаття другої половини XIX - 30-х pp. XX ст. вагоме місце займають термінологічні питання. Традиційними для української історичної науки є терміни «музейна справа» та музеєзнавство», які повною мірою не відображають стан розвитку вітчизняних сучасних наукових досягнень. Актуальність перегляду термінології музейної справи засвідчує діяльність Інституту історії України НАН України, у наукові працівники якого обгрунтовують термін «музейництво» як найбільш відповідний стану справ та досягнень української історичної науки. 
По-друге, хронологічні рамки дослідження історіографії музейництва на Прикарпатті другої половини XIX - 30-х pp. XX ст. теж характеризуються двовимірністю. Вона полягає у тому, що першим рівнем виступають хронологічні межі розвитку музейництва Прикарпаття впродовж другої половини XIX - 30-х pp. XX ст. Хронологічними межами тут виступають процеси зародження та розвитку музейної справи, що беруть початок з середини XIX ст. та тривають до радянської окупації 1939 року, коли, з встановленням тоталітарного режиму, музеї змінили свої функції, аудиторію відвідувачів, їхня діяльність почала строго регламентуватися існуючими ідеологічними рамками.

По-третє, територіальні рамки дослідження мають дворівневий характер. Перший рівень представлений територією Прикарпаття, що практично повністю співпадає з адміністративними межами Івано-Франківської області. Другий рівень територіальних меж дослідження представлений загальнопланетарним масштабом, оскільки дотримання принципів об'єктивності та сцієнтизму, зобов'язує здійснити історіографічний аналіз всіх наукових праць, автори яких проживають по сьому світу.

По-четверте, Тривалий науково-історичний процес дослідження музейництва на Прикарпатті другої половини XIX - 30-х рp. XX ст., різна етнічна приналежність науковців та інші фактори спричинили наявність широкого кола історіографічних джерел різноманітного характеру - від наукових статей та монографій до архівних зібрань та літератури мемуарного характеру.

По-п'яте, проблематика музейництва на Прикарпатті другої половини XIX - 30-х pp. XX ст. має складну структуру, пов'язану з багатоаспектною тематикою досліджуваного явища та багатоманітністю підходів до їі вивчення впродовж кількох історичних періодів. Окрім того, певної складності дослідженню додає синкретизм культурного життя та наукового процесу другої половини XIX - початку XX ст.

По-шосте, методологічні засади історіографічного дослідження музейництва на Прикарпатті другої половини XIX - 30-х pp. XX ст., базуються, з одного боку, на традиційних підходах та методах, що використовуються українською історичною наукою, а з іншого - характеризуються спрямованістю на адаптацію методологічних новацій. 
Основним підгрунтям вирішення дослідницьких завдань може стати така сукупність методів та підходів: логічний, порівняльний, ретроспективний, методи класифікації, періодизації, наукометрії, історичного аналізу, синтезу, історико-хронологічний, історико-ситуаційний, системно-структурного і проблемного підходу тощо.

По-сьоме, окреслені вище проблеми та концептуальні засади їхнього вирішення дозволяють стверджувати, що наявний методологічний інструментарій сучасної українська науки надає змогу здійснити комплексне історіографічне дослідження музейництва на Прикарпатті другої половини XIX - 30-х рр. XX ст.

У сучасній історичній науці немає жодного узагальнюючого історіографічного дослідження проблем формування та розвитку музейництва на Прикарпатті. Такі дослідження, здійснені на основі сучасних методологічних напрацювань досі залишається не вирішеною науковою проблемою.

\section{Список літератури:}

1. Вайдахер Ф. Загальна музеологія : посібник / Пер. з нім. В. Лозинський, О. Лянг, Х. Назаркевич. Львів : Літопис, 2005. 632 с.

2. Закон України «Про музеї та музейну справу» від 29 червня 1995 року № 249/95-BP. URL: https://zakon.rada.gov.ua/laws/show/249/95-вр (дата звернення: 28.02.2020).

3. Інститут історії України НAH України. URL: history.org.ua (дата звернення: 28.02.2020).

4. Калакура Я. Українська історіографія : Курс лекцій. Київ : Генеза, 2004. $496 \mathrm{c}$.

5. Кіян О. Методологічні принципи історіографічного синтезу: антропологічний контексті гносеологічні орієнтири. Наукові записки: історичні науки. Випуск 13. С. 250-260. URL: http://webcache.googleusercontent.com/ search?q=cache:jLe_eirU7HQJ:www.irbis-nbuv.gov.ua/cgi-bin/irbis_nbuv/ cgiirbis_64.exe \%3FC21COM\%3D2\%26I21DBN\%3DUJRN\%26P21DBN\%3D UJRN\%26IMAGE_FILE_DOWNLOAD\%3D1\%26Image_file_name\%3DPDF/ $\mathrm{Nz}$ i_2010_13_30. $\overline{\mathrm{pdf}}+\& \overline{\mathrm{cd}}=3 \& \mathrm{hl}=\mathrm{uk} \& \mathrm{ct}=\mathrm{clnk} \& \mathrm{gl}=\mathrm{ua} \& \mathrm{client}={ }^{-}$opera (дата звернення: $25 . \overline{02} .2020)$.

6. Маньковська Р. Музейництво в Україні: питання теорії та практики (1917 - червень 1941). Автореферат дисертації на здоб. наук. ст. канд. істор. наук (07.00.01), Інститут історії України. Київ, 1997. 21 с.

7. Реєнт О.П. Сучасна історична наука в Україні: шляхи поступу. УІЖ. 1999. № 3. С. 3-22.

8. Рутинський М.Й., Стецюк О.В. Музеєзнавство : навч. посіб. Київ : Знання, 2008, 428 с. 


\section{References:}

1. Vajdakher F. (2005). Zaghaljna muzeologhija: posibnyk / Per. z nim. V. Lozynsjkyj, O. Ljangh, Kh. Nazarkevych. Lviv: Litopys, 632 p.

2. Zakon Ukrajiny «Pro muzeji ta muzejnu spravu» vid 29 chervnja 1995 roku \# 249/95-VR. URL: https://zakon.rada.gov.ua/laws/show/249/95-vr (accessed 28.02.2020).

3. Instytut istoriji Ukrajiny NAN Ukrajiny. URL: history.org.ua (accessed 28.02.2020).

4. Kalakura Ja. (2004). Ukrajinsjka istorioghrafija: Kurs lekcij. Kyiv: Gheneza, $496 \mathrm{p}$.

5. Kijan O. Metodologhichni pryncypy istorioghrafichnogho syntezu: antropologhichnyj konteksti ghnoseologhichni orijentyry. Naukovi zapysky: istorychni nauky. (elektronic journal) no. 13, pp. 250-260. URL: http://webcache.googleusercontent.com/search? q=cache:jLe eirU7HQJ:www.irbis-nbuv.gov.ua/cgi-bin/irbis nbuv/cgiirbis_64.exe\%3FC21COM\%3D2\%26I21DBN\%3DUJRN\%26P21DBN\%3DUJRN\%26IMAGE_FILE_DOWNLOAD\%3D1\%26Image_file_name\%3D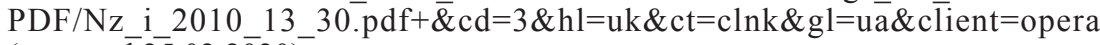 (accessed $\overline{25} .02 .2 \overline{0} 20$ ).

6. Manjkovsjka R. (1997).Muzejnyctvo v Ukrajini: pytannja teoriji ta praktyky (1917 - chervenj 1941). Avtoreferat dysertaciji na zdob. nauk. st. kand. istor. nauk (07.00.01), Instytut istoriji Ukrajiny. Kyiv, 2 p.

7. Rejent O.P. (1999). Suchasna istorychna nauka v Ukrajini: shljakhy postupu. UIZh, no 3, pp. 3-22.

8. Rutynsjkyj M.J., Stecjuk O.V. (2008). Muzejeznavstvo: navch. posib. Kyiv: Znannja, $428 \mathrm{p}$. 